\title{
Measuring the Gen Y Housing Affordability Problem
}

\author{
A. A. Bujang, W. R. Anthony Jiram, H. Abu Zarin, and F. H. Md. Anuar
}

\begin{abstract}
Most of the available research today focuses on housing affordability between different income groups, affordable housing and housing market, but very little work has been done on housing affordability for different generations. Hence, this paper focuses on housing affordability for the young generation, otherwise known as Gen Y. In general, the study on housing for Gen $\mathrm{Y}$ is inter-connected with the study on demographic factors. Gen $Y$ has been confronted with several housing issue which is the main housing issue for the Gen $Y$ often relates to affordability to buy. The main question often raised is whether at this young age, a person can afford to buy and owned a house? Therefore, this study is carried to verify the level of affordability among the young age people to buy and owned a house. This study is also carried out to identify the factors influencing the problems faced by this age group to buy and owned a house. Looking at it from the positive side, buying a house at young age can be an advantage where they can enjoy a longer financing period. The longer term financing is taken; the amount pay for housing loan can be a small sum.
\end{abstract}

Index Terms-Gen Y, house price, housing affordability, housing market, income.

\section{INTRODUCTION}

During this new era of human evolution, housing aspect has become a major concern in every corner of the world as the living standard of citizen's achievement represents a country's prosperity [1].

In brief, Malaysia had occurrence rapid urban growth since the 1950's due to the population increase and other economic activities. It has a strong relationship that can cause long term effects in various sectors especially in residential property market. These changes refer to the population, immigration, education, household size, and income structure [2]. The high rate of urban growth due to migration, increase in population size and distribution of income have significantly contributed to the growth of housing in our country. At this stage the function of housing had changed due to the increasing in demand as well as the price fluctuation which in turn the buying a property is much differ with the affordability level. In fact, the affordability level is essential for a person to buy and own a residential property where it can be influenced by demographic factors which buyer's age is one of them [3].

Manuscript received October 10, 2014; revised February 1, 2015. This work was supported by Universiti Teknologi Malaysia under the Research University Grant Scheme Vot. 08H91.

A. A. Bujang is with the Department of Real Estate, Faculty of Geoinformation and Real Estate, Universiti Teknologi Malaysia, 81310 Johor Bahru, Malaysia (e-mail: ahamadariffian@utm.my).

W. R. Anthony Jiram and H. Abu Zarin are with Universiti Teknologi Malaysia, 81310 Johor Bahru, Malaysia (e-mail: wilson.rangga@live.com.my, hasmah@utm.my).

F. H. Md. Anuar was with Universiti Teknologi Malaysia, 81310 Johor Bahru, Malaysia.
In explaining the relationship between demographic, house prices and housing affordability, it became a classic problem in housing market since there is an ever of increasing volume of literature detailing the remarkable of how the affordable housing needs and the populations are related in Malaysia. Norhaslinda [1] and Idrus and Ho [4], carried out a study on demographic factors that influenced housing affordability. However, most of the research carried out focused on housing for certain income group but not the age group or generation.

Thus the common question is does the age factors influenced the housing affordability. Is it true that the young generation faced problems to buy and owned affordable housing? In other words, why only a few from this group afford to buy and own house. What are the financial commitments of the young generation?

\section{LITERATURE REVIEW}

\section{A. Gen $Y$}

Gen $\mathrm{Y}$ is the demographic cohort including individuals born between the years of 1979 and 1994, which has been dubbed as "Echo Boomers", "Generation Next", "Net Generation", or "Millennials". Young adults of this generation are children of either "Baby Boomers" or "generation Xers" [5]. Gen Y is a cohort made up of about 60 million individuals who are all said to have very different preferences and characteristics than that of their predecessors. The age or life-stage of this generation makes them unique from other cohorts. As there are no precise dates for when the Gen Y starts and ends, it depending upon the demographers and many have used birth dates ranging somewhere from the mid 1970's to the early 1994.

\section{B. The Characteristics of Gen $Y$}

Generally, not everyone in a generational cohort behave alike to those at another. The key behaviours and preferences are differs significantly at the previous generation within same age and which are likely to become part of their ultimate culture.

Gen Y tends to have high moral spirit, patriotic, willing to fight for freedom, sociable and emphasize the value of home and family. Gen $\mathrm{Y}$ is the generation of technically literate, educated and ethnicity and tends to earn more. They are faced with the intellectual challenge, the need to success, strive to make a difference from others and measure their own success. According to Allen [6], Gen Y more strained on contribution to the community in enjoying a balanced life. They emphasize their free time to spend with family, entertainment and sports rather than work even they are offered a much higher salary.

The Echo Boomer (Gen Y) is a particularly powerful market segment because they are used to having a number 
of possessions [7]. Demographers, market analysis and researches already realize that this group will dominate marketing in the twenty-first century [8]. Gen Y'ers loves to spend their time with radio, television and the internet. It is an appropriate media for attracting the teen market through mass marketing efforts. This generation is very brandconscious and loyal [7]. Today's younger generation is much more tolerant and much more receptive to diversity. Furthermore, today's parent more concerned about assuring financially secure future for Gen Y'ers. They continue to purchase stocks (including mutual funds) and bonds for their children for their future.

They have different financial commitments; thus more than 70 percent of their income is discretionary, with the majority going to entertainment, travel and food [9]. Overall, generation $\mathrm{Y}$ appears to have a positive attitude toward shopping as a fun experience [10]. Importantly, Lehtonen and Maenpaa [11] indicated that this generation lives in an era in which shopping is not regarded as a simple act of purchasing a product.

Gen Y will have a tremendous impact on housing. There are many young households and those in single incomes who aspire to home ownership and strongly motivated, but lack sufficient to achieve it. Many modest-income households entering home ownership have a greater risk of housing affordability problems in the future.

\section{Definition and Concepts of Demographic and Housing Affordability}

Housing affordability always correlated with the price exists in the market. Demographic development is one of the circumstances that led in these prices in the local market. Correlation analysis between demographic factors and housing markets is relatively attractive based on the premise that demographic elements are the key drivers of property market, whereby some people believe that the relationship exists in the market only in the long run.

Mulder [12] and Plane [13], defined demographic as a study of human populations with emphasises on the statistical analysis of the quantities and characteristics of the people who live in a certain areas, especially with regard to their age, how much money they have, and what they spend it on. According to Plane [14], demographic studies involving the measurement of size, growth, density, distribution, and diminution of the number of people, the proportion of living, being born, or dying, within some area or region, and the related functions of fertility, mortality and marriage. Thus, demography can be summarized as a study of the characteristics of human populations such as size, growth, density and distribution.

Bujang [3], and Watson and Eggers [15] noted that families who pay more than 30 percent of their income for housing are considered cost-burdened and may have difficulty to meet basic necessities such as food, clothing, transportation, and medical care. Housing affordability can also be seen as a gauge used to evaluate the ability of households is based on one-third or 30 percent of its total income [3], [16]. Housing affordability serves as a key indicator for the housing sector. Generally, it is defined as a person's ability to finance the cost of home ownership in financial terms [17]. Housing affordability can also be seen when the person was still capable to finance other needs besides housing costs with the rest of his income [18].

Affordable housing is generally designed to meet the needs of a range of low- to medium income households whose incomes are insufficient to enable them to access suitable housing in the market without assistance and other essential basic living costs. In the US, the broad characteristics of 'affordable housing' are that is privately owned, socially oriented, and price restricted [19]. Thus, the 'affordable housing' terms describes housing that assists lower income households in obtaining and paying for suitable housing without suffering undue financing hardship [20].

Bujang [3] also pointed out, the general housing affordability price in Malaysia is less than RM150,000 per unit, especially for the Bumiputera and medium income group. Housing affordability can also be viewed in three different ways: purchase affordability, repayment affordability and income affordability [21].

\section{Demographic Factors Influence Housing Market and Affordability}

Idrus and Ho [4] demonstrated that demographic factors are important variables for housing prices determination in the long term. Affordability remains a major concern due to high prices of existing properties and the lack of supply of affordable and well located properties within urban centre. The most important factors influencing housing affordability are price, location and population's socio economic environment [22].

Idrus and Ho [4] listed it among other factors that affect demand for housing in the market. They are the role of the demographic, satisfaction and personal preference of resident. They then elaborated that personal preference varies by housing categories, zones, size of projects and period of projects. Iman [2] cited that property demand could be categorised according to its physical, location, population, socio economic, and market. Myers [23] categorized socio economics, market and demographic determinants as macro factors. Among these factors are population size, population age, income and affordability of saving. Myers [23] and Sirat [24] pointed out that the demographic factors may affect the demand for housing, whereby the higher demand is associated with the bigger population. Meanwhile, age distribution favouring the time period of starting up a family will impact a greater need for housing. The wealth factors as well as the net return to home ownership like employment, education level, and household's income are very positively related with the demand and affordability level.

Linneman and Megbolugbe's [25] interpreted that the problem of affordability level especially for lower and middle class households is due to the low levels of job skills and education that they had. It then, began to experience affordability problems for these groups of people, not because of the housing prices had increased dramatically, but their incomes became stagnant and could not cope with the price offered in the market.

\section{E. Housing Ownership Issues in Malaysia}

Osman [26], housing problems and issues in Malaysia arise from the urbanisation and industrialisation process. 
These processes bring along many immigrants from the rural areas. Hence, it created high demand for housing, especially for the immigrants for the lower and medium income groups. Thus, it also created housing problems in the urban area. Yusof and Razali [27], urbanisation and industrialisation are the main factors that pushed up the demand of housing in the urban areas, especially from the lower and medium income groups.

Housing problems can also arise when the developers in the urban areas, have less interested to build medium and low cost housing. This is because the margin and profit earned is small. Private housing developers controlled most of the land in major towns and cities are interested to develop high cost or luxury housing for bigger margin or profit. Thus, the immigrant found that the price of the houses offered in the urban area is beyond their affordable income [27]. Hence, it created housing problems to the immigrants with medium and lower income especially in the urban areas.

Discontentment among young adults over high property prices offered by the private developers, which is sometimes speculated by the developers for bigger margin. Moreover, the price increases are not commensurate with salary increases. It makes young adults feel difficult to catch up with the house prices. Gen $\mathrm{Y}$ also faced difficulties in securing loan or end financing from banking and financial institutions. Problem to allocate 10 percent deposit of the selling price is the biggest barrier for the first home buyers. This deposit is to be paid upon signing the Sale and Purchase Agreement, required under The Housing Developer's Act (Licensing and Controlled 1966) as part of progress payments. Thus, if the selling price of the house is high, then the 10 percent deposit needs to be paid although it's high and burden to the buyers.

Most of young adults tied to car loans and credit card bills to settle before they can ever think of getting a house. Renting is an option as they just have to pay slightly less than the monthly mortgage payment for a comfortable house. Hence they cannot save enough for the down payment. This category of income earners ends up renting for many years. Some may end up being homeless when they grow old or retire.

Thus from the above literatures, the question of buying a house by this Gene $\mathrm{Y}$ is often left out or less priority. Therefore, in the Malaysian Budget 2011, the Prime Minister of Malaysia announced a special program to assist the young generation to buy and own a house. The My First Home Scheme aimed is to ease the burden of younger generation who are facing in increased of cost of living and increased in property prices. It is open to young people who have just joined the workforce and who are earning RM3,000 or less per month to own their first home. Under the scheme, they will be exempted from the standards 10 percent down payment for the property they are interested in purchasing and obtain 100 percent financing from financial institutions.

\section{Methodology}

Quantitative approach was used to gather and analyze the data. Secondary data is gathered from previous studies and published articles or resources such as journals, annual reports and books. Basically, the aim of the literature review is to gather information of the definition on housing affordability, generation $\mathrm{Y}$ and demographic factors. It also discussed the factors that influence generation $\mathrm{Y}$ housing affordability problems. Meanwhile primary data are gathered direct from it sources. The questionnaires are formulated and designed according to the research problems and objectives which are divided into open ended and closed ended questions. The questionnaire survey has been carried out to identify and measure the factors that influence Gen Y housing affordability.

The samples used in this study are taken at random probability at a degree of confident of 90 percent by using Taro Yamane [28] formula. Therefore, the minimum sample of this study is 100 . Reliability test on the instrument has been carried out and exceeded the threshold of 0.7. Next, the data collected are then analyzed by using computer software, Statistical Package for Social Science version 17 to carry out a descriptive analysis.

\section{ANALYSIS AND INTERPRETATION}

House hold income and individual level of monthly incomes are important to determine the housing affordability among the young generation or generation Y. Table I shows the analysis on house hold level of monthly income in the study area. While Table II shows the analysis on individual level of monthly income.

TABLE I: THE ANALYSIS ON THE LEVEL OF MONTHLY INCOME OF HOUSEHOLD

\begin{tabular}{lcc}
\hline \hline \multicolumn{1}{c}{ Level of monthly income } & Frequency & Percent (\%) \\
\hline Below RM3,000 & 16 & 14.0 \\
RM3,001 - RM3,999 & 7 & 6.1 \\
RM4,000 - RM4,999 & 13 & 11.4 \\
RM5,000 - RM5,999 & 13 & 11.4 \\
RM6,000 - RM6,999 & 1 & 0.9 \\
RM7,000 - RM7,999 & 6 & 5.3 \\
RM8,000 - RM8.999 & 5 & 4.4 \\
RM9,000 - RM9,999 & 4 & 3.5 \\
RM10,000 and above & 8 & 7.0 \\
Not related & 41 & 36.0 \\
Total & 114 & 100.0 \\
\hline \hline
\end{tabular}

TABLE II: THE ANALYSIS ON THE LEVEL OF INDIVIDUAL MONTHLY INCOME

\begin{tabular}{lcc}
\hline \hline Level of individual monthly income & Frequency & Percent (\%) \\
\hline Below RM1,000 & 9 & 7.9 \\
RM1,001 - RM1,999 & 30 & 26.3 \\
RM2,000 - RM2,999 & 31 & 27.2 \\
RM3,000 - RM3,999 & 15 & 13.2 \\
RM4,000 - RM4,999 & 11 & 9.6 \\
RM5,000 and above & 18 & 15.8 \\
Total & 114 & 100.0 \\
\hline \hline
\end{tabular}

From the above analysis it is found that most of the respondent either household or individual level of monthly incomes are below RM3, 000. Thus it can be concluded that 
they can be categorised under the medium and medium high income groups.

Table III shows the analysis on affordable housing price among generation $\mathrm{Y}$ in the study area.

TABLE III: AFFORDABLE PURCHASED PRICE FOR THOSE ALREADY OWNED A HOUSE

\begin{tabular}{lcc}
\hline \multicolumn{1}{c}{ Housing price } & Frequency & Percent (\%) \\
\hline Below RM50,000 & 6 & 5.3 \\
RM50,001 - RM69,999 & 2 & 1.8 \\
RM70,000 - RM99,999 & 12 & 10.5 \\
RM100,000 - RM149,999 & 8 & 7.0 \\
RM150,000 - RM199,999 & 13 & 11.4 \\
RM200,000 - RM249,000 & 4 & 3.5 \\
RM250,000 - RM299,999 & 4 & 3.5 \\
RM300,000 - RM349,999 & 1 & 0.9 \\
RM350,000 - RM399,999 & 3 & 2.6 \\
RM400,000 and above & 3 & 2.6 \\
Not related & 58 & 50.9 \\
Total & 114 & 100.0 \\
\hline \hline
\end{tabular}

From the above analysis it is found that the affordable housing price among house hold Generation $\mathrm{Y}$ is below RM200, 000 per unit. The analysis showed most of them who already purchased a house with the price of below RM200, 000 per unit. Table IV then shows the analysis on affordable purchased price for those who are still looking for a house.

TABLE IV: AfFordable Purchased Price for Those Are Still

\begin{tabular}{lcc}
\multicolumn{3}{c}{ LOOKING FOR A HousE } \\
\hline \hline House price & Frequency & Percent (\%) \\
\hline RM70,000 - RM99,999 & 30 & 26.3 \\
RM100,000 - RM149,999 & 5 & 4.4 \\
RM150,000 - RM199,000 & 7 & 6.1 \\
RM200,000 - RM249,999 & 9 & 7.9 \\
RM250,000 - RM299,999 & 1 & 0.9 \\
RM300,000 - RM349,999 & 4 & 3.5 \\
RM350,000 - RM399,999 & 1 & 0.9 \\
RM400,000 and above & 1 & 0.9 \\
Not related & 56 & 49.1 \\
Total & 114 & 100.0 \\
\hline \hline
\end{tabular}

The above analysis also found that the affordable price among individual generation $\mathrm{Y}$ is the same as house hold which is below RM200, 000 per unit. Most of the respondents choose below RM 200,000 as their affordable house to buy or looking for. Table V shows an analysis on the factors influencing Generation $\mathrm{Y}$ housing affordability problems.

From the above analysis, it is found that housing deposit too high is the most influencing factor on Generation $\mathrm{Y}$ housing affordability problems with an average score of 4.2807. Next house price within affordability is not in the market with an average score of 4.2105. High monthly installment and financing eligibility are also important factors influencing Generation $\mathrm{Y}$ housing affordability problems. Both factors have average score of 4.1930 and 4.0263 respectively.
TABLE V: THE ANALYSIS ON THE FACTORS INFLUENCING GEN Y HOUSING AFFORDABILITY PROBLEM

\begin{tabular}{lc}
\hline \hline Factors & Average Score \\
\hline Housing deposit too high & 4.2807 \\
Lack of houses within affordability price in & \\
the market & 4.2105 \\
High monthly installment & 4.1930 \\
Financing eligibility problems & 4.0263 \\
Location not suitable & 3.7281 \\
Design not suitable & 3.2281 \\
Engaged with other financing commitment: & \\
Personal loan & 3.3859 \\
Educational loan & 3.2544 \\
Credit card & 3.0526 \\
Elegant life style & 2.9386 \\
High living expenses & 2.9210 \\
\hline \hline
\end{tabular}

\section{CONCLUSION}

Based on the study, the most important finding is housing affordability for Generation $\mathrm{Y}$ with the price less than RM200, 000 per unit and monthly income earned level is RM3, 000. The factors influencing generation $\mathrm{Y}$ housing affordability problems are difficulty to pay deposit, house prices are too high, lack of affordable houses supply in the market, house size is small, difficulty to secure loan, and earned low income.

\section{REFERENCES}

[1] N. Jumadi, "The influenced of demographics factors on residential property market," M.Sc. Thesis, Dept. Property Management, UTM, JB, 2008.

[2] A. H. M. Iman, An Introduction to Property Marketing, UTM, 2002.

[3] A. A. Bujang, "Residential property ownership: an evaluation study on the Bumiputera lot quota ruling in the district of Johor Bahru," Ph.D. Thesis, Universiti Malaya, Kuala Lumpur, 2006.

[4] N. Idrus and C. S. Ho, "Affordable and quality housing through the low cost housing provision in Malaysia," Dept. Town \& Regional Planning, Faculty of Built Environment, Universiti Teknologi Malaysia, 2008.

[5] E. Neuborne and K. Kerwin. (1999). Generation Y. Business Week [Online]. http://www.businessweek.com/1999/99_7/b361.6001.htmf

[6] P. Allen, "Welcoming $Y$ Generation $Y$ ' is just entering the workforce. Employers need to know how to evolve benefits plans to attract and retain this new generation," Benefits Canada, vol. 28, no. 9, pp. 51$56,2004$.

[7] K. Gronbach, "Generation Y-not just 'kids'," Direct Marketing, vol. 63, no. 4, pp. 36-43, 2000.

[8] M. L. Alch, "The echo-boom generation: A growing force in American society," Futurist, vol. 34, no. 5, pp. 42-51, 2000.

[9] M. McCrindle, "Understanding generation Y," Principal Matters, vol. 55, pp. 28-31, 2003.

[10] V. Zeithaml, "The new demographics and market fragmentation," Journal of Marketing, vol. 49, pp. 64-75, 1985.

[11] T. K. Lehtonen and P. Maenpaa, "Shopping in the East Center Mall," in The Shopping Experience, P. Falk and C. Campbell, Eds. London: Sage Publication, 1997.

[12] C. H. Mulder, "Population and housing: A two sided relationship," Demographic Research, vol. 15, pp. 401-412, 2006.

[13] D. A. Plane, "The post-Trewartha boom: The rise of demographics and applied population geography," Population, Space and Place, vol. 10, no. 4, pp. 285-288, 2004.

[14] D. A. Plane, "Demographic influence on migration," Regional Studies, vol. 27, issue 4, pp. 375-383, 1993.

[15] G. Watson and F. Eggers, "Rental market dynamics: Is affordable housing for the poor an endangered species," U.S. Department of Housing and Urban Development (HUD), 2003.

[16] C. K. T. David, From Past to Present - The Developers' Perspective, 1997.

[17] M. S. Norazmawati, "Low-cost housing ownership and affordability in Kuala Lumpur," Ph.D. Thesis, Universiti Sains Malaysia, Pulau Pinang, 2007. 
[18] C. M. Whitehead, "Urban housing markets: Theory and policy," Handbook of Regional and Urban Economics, vol. 3, pp. 1559-1594, 1999.

[19] E. Davis, The Affordable City, Temple University Press, 1994

[20] V. Milligan, P. Phibbs, K. Fagan, and N. Gurran, "A practical framework for expanding affordable housing services in Australia Learning from experience," Final Report 61, Australian Housing and Urban Research Institute, Melbourne, 2004.

[21] Quan and Hill, "Measuring housing affordability: Looking beyond the median," Discussion Papers 2008-09, School of Economics, The University of New South Wales, 2008.

[22] P. H. Rossi, Why Families Move, London: Sage Publications, 1955.

[23] D. Myers, Housing Demography — Linking Demographic Structure and Housing Markets, The University of Wisconsin Press, Wisconsin, 1990.

[24] M. Sirat, Low-Cost Housing in Urban-Industrial Centres of Malaysia: Issues and Challenges, Penerbit Universiti Sains Malaysia, 1999.

[25] P. Linneman, "Megbolugbe's, Housing Affordability. Myth or Reality?" Urban Studie, vol. 1, no. 29, pp. 369-392, 1992.

[26] T. Osman, Globalisation, Patriotism and Public Issues, Kuala Lumpur: Universiti Malaya Press, 2004.

[27] A. M. Yusof and A. Razali, "House price discovery in Malaysia: A preliminary analysis," presented at the International Real Estate Research Symposium (IRERS), Kuala Lumpur, Malaysia, 2004.

[28] T. Yamane, Statistics: An Introduction Analysis, Harper \& Row, 1973.
Ahmad Ariffian Bujang is currently an associate professor at the Faculty Geoinformation and Real Estate in Universiti Teknologi Malaysia (UTM) $\mathrm{He}$ also is a registered valuer under Board of Valuers, Appraisals and Estate Agents Malaysia. He received his Ph.D. degree in Universiti Malaya. His specialization is in valuation and property investment. He is also interest in statutory valuation. He has published several research papers and books on aforementioned topics.

W. R. Anthony Jiram received his B.Sc. degree of property management and M.Sc. degree of real estate from Universiti Teknologi Malaysia. Currently, he is doing Ph.D. degree in real estate at Universiti Teknologi Malaysia, Malaysia. His current research is focused on real estate education. He also interested in housing and property management area and has published several research papers on aforementioned topics.

Hasmah Abu Zarin received her B.Sc. degree from Franklin University, Columbus Ohio, U.S.A. in real estate and her master degree in land economy from Abeerden University, Scotland, UK. Currently, she is a senior lecturer at Universiti Teknologi Malaysia. Her current research is focused on valuation, economy and planning. She also interested in sustainability area has published several research papers on aforementioned topics. She is a member of Institution of Surveyors Malaysia from 1999 until now.

Fara Hanan Md. Anuar received her B.Sc. degree of property management and M.Sc. degree of real estate from Universiti Teknologi Malaysia, Malaysia. Her research is focused on housing affordability. 